\title{
The value of therapeutic planning and the degree of experience of the surgical team on the results of cancer treatment of the larynx and hypopharynx
}

\author{
Head and Neck Surgery Service of the Heliopolis Hospital Complex, São Paulo. \\ Locus-Advanced Center-Head and Neck - São Paulo, Brazil
}

\begin{abstract}
This is a prospective study supported by 170 cases of epidermoid carcinoma of the larynx or hypopharynx, treated during the period from January of 1981 to January of 1988, at the Head and Neck Surgery Service of the Heliópolis Hospital Complex, São Paulo. The objective of this project was to evaluate the importance of surgeon experience with regard to the rates of post-operative complications and the rates of relapse and survival. The results of the 8 surgical specialists who integrate the permanent staff at the institute and who different varying degrees of experience with regard to time spent exercising their specialties were compared. The results obtained did not show a significant difference among the various surgeons, and this uniformity is explained by the fact that all the therapeutic planning was elaborated through consensus of the whole group, and this could have minimized the effect of experience of a surgeon responsible for the operation. The authors emphasize the importance of pre-operative evaluation for good results and propose that it is in the direction of complete mastery of preliminary work in the area that programs for the formation of new specialists should be directed.
\end{abstract}

UNITERMS: Larynx and hypopharynx neoplasia. Laryngectomy. Complications. Survival. Head and neck surgery. Training and formation of specialists.

\section{INTRODUCTION}

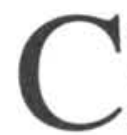
ancer in the upper aero-digestive tract has been, more and more, a territory reserved for the work of a specialist in head and neck surgery. This argument gains weight when we restrict ourselves to

\section{Address for correspondence:}

Marcos Brasilino de Carvalho

Praca Amadeu Amaral, 47, Conjunto 82

Sao Paulo/SP - Brasil - CEP 01327-010 tumors of the larynx and hypopharynx. Clinical evaluation of these neoplasias is difficult as there are various degrees of malignancy, based on macro and microscopic characteristics. The natural history of the tumors varies according to their exact location. Once the clinical diagnosis is made and the staging of the lesion determined, histological confirmation leads to the therapeutic choise.

The objective of this study is evaluating whether or not, after the definition of treatment, the experience of the specialist doing the surgery has a significant impact on the results. 


\section{CLINICAL DATA AND METHODS}

This paper is based on the prospective analysis of 170 cases of epidermoid carcinoma of the larynx or hypopharynx, treated from January of 1981 to January of 1988, at the Head and Neck Surgery Service of the Heliópolis Hospital Complex, São Paulo.

Before the treatment proposal was defined, the patient was presented to the whole team of surgeons and the following items were debated: how long the patient had had the problem, the general condition, the location of the neoplastic lesion, its extension, its stage and histological type. A decision as to the adequate treatment was taken through consensus of the whole group.

All the patients were submitted to resection of the primary lesion (laryngectomy or pharyngolaryngectomy) in one block with comprehensive neck dissection. These surgeries were led by eightsurgeons that belong to the permanent staff of the institute. Of these, half (subgroup $x)$, represented the basic founding group of the Surgery Service, and who participated actively in the formation and training of the others (subgroup y), who were younger but recognized as fully capable of performing surgery according to the correct oncologic parameters. The participation of the various surgeons in these cases was not at random and was determined by the operational routine demand of the institution. Subgroup $\mathrm{x}$ performed 78 surgeries $(45.9 \%)$ and subgroup y, $92(54.1 \%)$.

During the analysis of the results the eight surgeons were designated by numeric code from 1 to 8 , and identification was not known until the end of the analysis of the data. An attempt was made to observe a correlation between the experience of the surgeon and the rates of complications, recurrence and survival. In the analysis of the rates of relapse and survival only 115 patients were considered, excluding the 55 remaining which showed metastatic lymph nodes with transcapsular spread.

The calculations for global survival (GS) and survival free of disease (SFD) was done using the KAPLAN \& MEIER technique ${ }^{(3)}$. The computer program KMSURV ${ }^{(1)}$ was used for the statistical analysis. Regression techniques of $\mathrm{COX}^{(2)}$ were employed with the aim of predicting, separately, the risks of relapse and of death, when comparing the data of the coordinating author in this work (MBC) with those obtained by the other members of the Surgery Service.

\section{RESULTS}

Table I shows the complications by surgeon and Table II shows the distribution of the post-operative complications between the two subgroups of surgeons and the differences observed were not statistically significant. There were no post-operative complications in $69(40,6 \%)$ of the patients.

Figures I and II show, respectively, the actuarial curves of survival free of disease and the global survival

Table I

Distribution of the post-operative complications by surgeon

\begin{tabular}{|c|c|c|c|c|c|c|c|c|}
\hline \multirow[t]{2}{*}{ type } & \multicolumn{8}{|c|}{ surgeon } \\
\hline & 1 & 2 & 3 & 4 & 5 & 6 & 7 & 8 \\
\hline \multirow[t]{2}{*}{ fistula } & 11 & 10 & 12 & 3 & 5 & 1 & 8 & 4 \\
\hline & 36.7 & 35.7 & 40.0 & 26.7 & 29.4 & 20.0 & 22.9 & 40.0 \\
\hline \multirow[t]{2}{*}{ necrosis and dehiscence } & 9 & 5 & 11 & 3 & 6 & 1 & 10 & 6 \\
\hline & 30.0 & 17.9 & 36.7 & 20.0 & 35.3 & 20.0 & 28.6 & 60.0 \\
\hline \multirow[t]{2}{*}{ infection } & 2 & 4 & - & 2 & 2 & 2 & 6 & - \\
\hline & 6.7 & 14.3 & & 13.3 & 11.8 & 40.0 & 17.1 & \\
\hline \multirow[t]{2}{*}{ death } & - & 2 & 1 & 2 & 2 & - & 4 & - \\
\hline & & 7.1 & 3.4 & 13.4 & 11.8 & & 11.4 & \\
\hline \multirow[t]{2}{*}{ no complication } & 13 & 12 & 11 & 8 & 5 & 1 & 15 & 4 \\
\hline & 43.4 & 42.9 & 36.7 & 53.3 & 29.4 & 20.0 & 42.9 & 40.0 \\
\hline
\end{tabular}


Table II

Distribution of the post-operative complications by subgroup

\begin{tabular}{lccc}
\hline type & sub-group $\times(\%)$ & sub-group y (\%) & total \\
\hline \multirow{2}{*}{ fistula } & 25 & 29 & 54 \\
& 30.1 & 21.5 & 31.8 \\
necrosis and & 18 & 33 & 51 \\
dehiscence & 23.1 & 35.9 & 30.0 \\
& & & \\
infection & 10 & 8 & 18 \\
& 12.8 & 8.7 & 10.6 \\
death & 4 & 7 & 11 \\
& 5.1 & 7.6 & 6.5 \\
& & & \\
no complications & 34 & 35 & 69 \\
& 43.6 & 38.0 & 40.6 \\
\hline
\end{tabular}

comparing the results obtained by the author with those of the others of the members of the team. The differences observed were not statistically significant (p. 0.8060 and 0.9188).

Table III shows the risks relative to recurrence and death and again there was no significant difference compared to the other surgeons of the Department of Surgery.

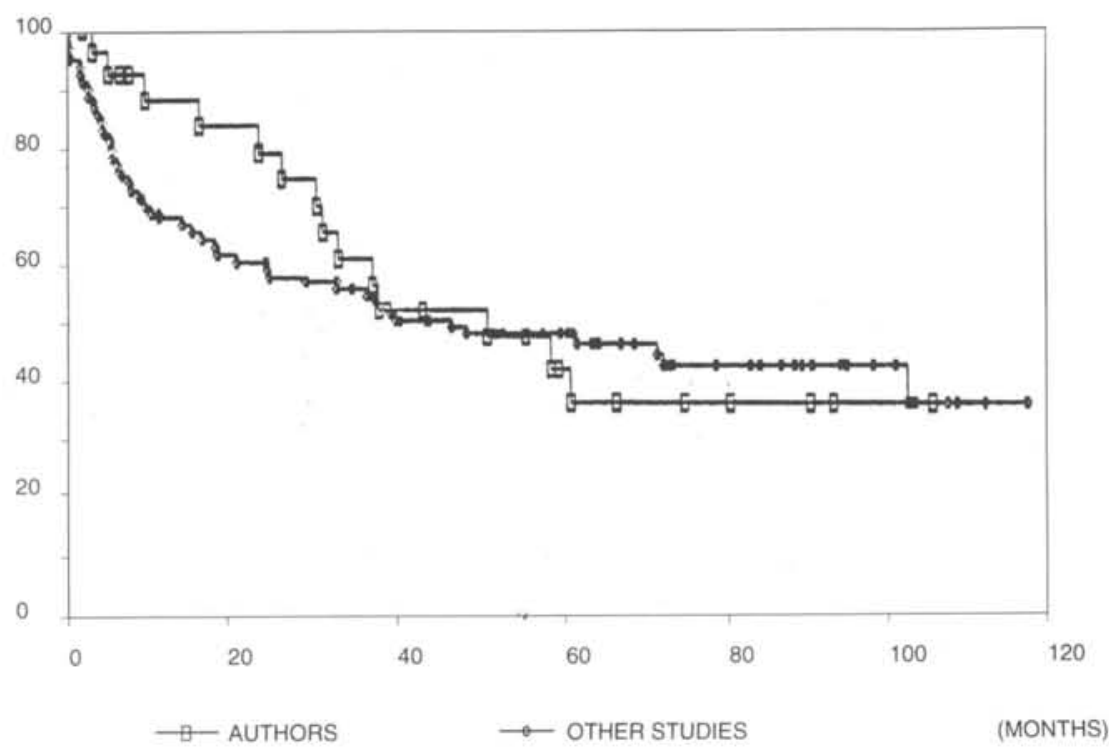

\section{Table III}

Relative risks of recurrence and death

\begin{tabular}{ccccc}
\hline & $\begin{array}{c}\text { RR of } \\
\text { recurrence }\end{array}$ & IC 95\% & RR of death & IC 95\% \\
\hline author & 1.00 & ref. & 1.00 & ref. \\
others & 1.07 & $0.59-1.95$ & 1.03 & $0.55-1.92$ \\
\hline
\end{tabular}

\section{DISCUSSION}

The efficiency of surgical treatment is linked fundamentally to the criteria of indication, the severity of the disease and the technical expertise of the surgeon. The severity of consequences that can follow inappropriate or untimely treatment is observed daily in the out patient clinic of Head and Neck Surgery Department. Cancer of the larynx and of the hypopharynx are diseases of usually unfavorable prognosis and with fairly complex indications for treatment.

This complexity comes from the multiplicity of variables that need to be considered when choosing the best treatment. On the other hand, the operation itself, even though it demands from the surgeon perfect knowledge of anatomy and of the principles of oncological surgery, has been standardized for years as to timing and sequence and is easily mastered by the specialists in this area. Its important to remember that the cases in which macroscopic capsular rupture was detected were excluded from the analysis on global survival and survival free of disease, since for these cases the prognosis is invariably very unfavorable and this could distort the results.

The results of this study show that, by guaranteeing the criteria of an adequate indication, the treatment will be effective regardless of the experience of the surgeon, provided that an adequate level of training suitable for the realization of an oncological and technical surgery has been assured. In such a way, the training of new specialists of head and neck surgery should be centered around assuring and solid theoretical knowledge of the natural history of diseases that affect this region, these being essential for a satisfactory outcome.

Figure 1. Actuarial curve of survival free of disease 


\section{CONCLUSION}

In the surgical treatment of cancer of the larynx and of the hypopharynx, when correctly indicated and conducted by efficient, recognized specialists, the incidence of complication and the rates of recurrence and survival are independent of the experience of the surgeon. All the efforts of the attending team should be concentrated on the pre-surgical evaluation of the cases, so as to assure an adequate therapeutic plan.

\section{ACKNOWLEDGMENTS}

The authors thank Dr. Luiz Paulo Kowalski for the statistical analysis of these cases.

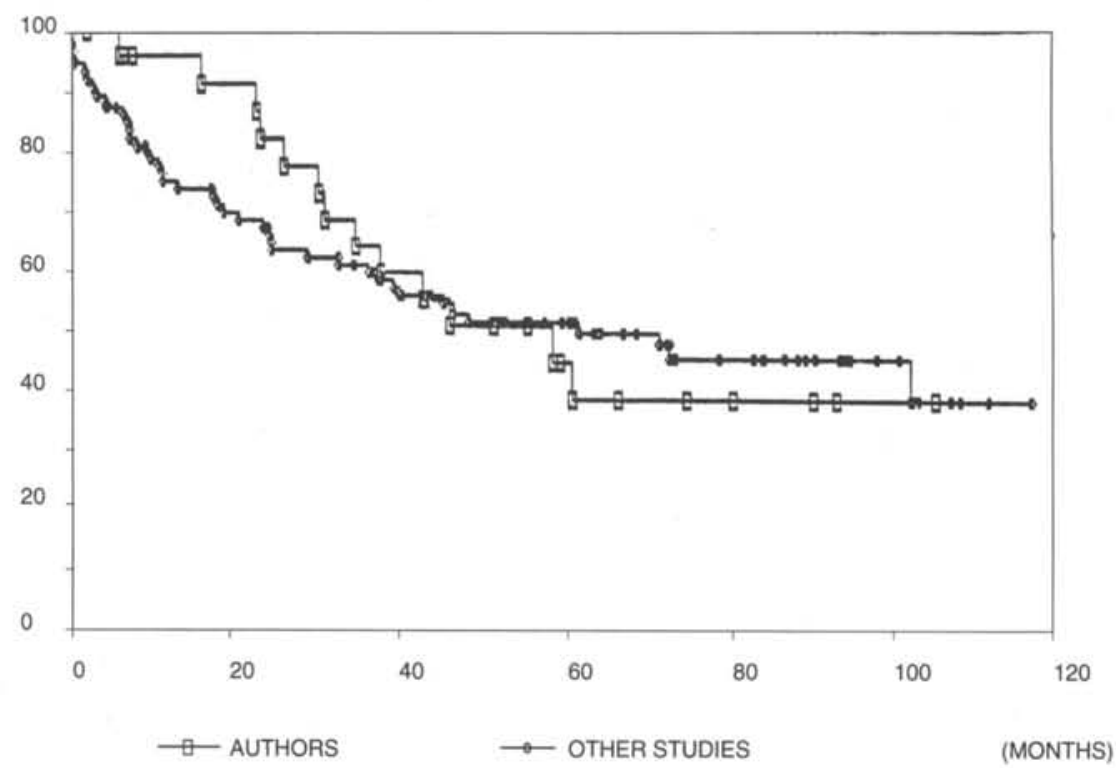

Figure 2. Actuarial curve of global survival

\section{ReSUMO}

Objetivo: avaliar a importância da experiência do cirurgião nos índices de complicação pós-operatória e nas taxas de recidiva e de sobrevida. Material e Métodos: foram comparados os resultados obtidos pelos 8 cirurgiōes especialistas integrantes do quadro permanente do Serviço e que possuiam graus variados de experiência considerando o tempo de exercicio da especialidade. Resultados: os resultados observados nāo apresentaram diferença significante entre os vários cirurgiōes e esta uniformidade é explicada pelo fato de que todo o planejamento terapêutico foi elaborado por consenso de todo o grupo e isto pode ter minimizado uma menor experiência do cirugiâo responsável pela conduçāo do ato operatório. Conclusōes: os autores enfatizam a importância da avaliação pré-operatória como uma condiçāo para que bons resultados sejam esperados e propōem que é na direção do completo domínio da propedêutica da região que devem ser dirigidos os programas de formaçāo de novos especialistas.

\section{REFERENCES}

1. CAMPOS FILHO, N. \& FRANCO, E.L. - Microcomputer assisted univariate survival data analysis using Kaplan-Meier life table estimators. Computer Methods Programs Biomed 27: $223-28,1988$.
2. COX, D.R. - Regression models and life-tables. J R Static Soc Br 34: 187-220, 1972.

3. KAPLAN, E.L. \& MEIER, P. - Nonparametric estimation from incomplete observations. J Am Static Assoc 53: 457-81, 1958. 